\title{
THE CORRESPONDENCE OF LUCIEN TESNIÈRE AS PRESERVED IN THE MANUSCRIPT COLLECTION OF SLOVENE NATIONAL AND UNIVERSITY LIBRARY IN LJUBLJANA
}

\section{Introduction}

L. Tesnière's three year's stay in Ljubljana (1921-1924) resulted in his personal contacts with a selected group of eminent Slovene scientists and creative writers. Some of them later established an interesting correspondence with him. So far 17 Tesnière's letters from the period 1921-1938 have been identified in the Manuscript collection of NUK. They are addressed to Ivan Prijatelj (3, 1921-1923), Oton Župančič (2, 19231928), Anton Debeljak (2, 1923-1938) and Joža Glonar (10, 1924-1934). It is reasonable to expect that some more of his letters will come into our evidence when the literary archives of our philologists and men of letters who were active in the period 1920-1954 will be thoroughly inspected. Nevertheless, T.'s correspondence as preserved in our library even in its present modest extent represents important and interesting material for further research work in his life and scientific activity.

\section{Letters to dr. Ivan Prijatelj (1875-1937)}

Out of three T.'s letters to his faculty dean only this first one, dated 28 Jan. 1921, has a typical handwritten letter form. Two practical matters are discussed in the first part, the first being T.'s request to postpone the beginning of his lectures for two days due to his travelling to Zagreb where he is planning to see all the necessary documents and other formalities about his marriage. Therefore he'd be able to start his lectures on 31 January. Two interesting and perhaps important pieces of information can be obtained from these lines: L. T. most likely got married on Saturday, 30 Jan. 1921, and his first lecture was delivered on Monday, 31 Jan. 1921.

The other official matter is his promise that he will give his approval and signature to the belated student applicants no later than $7 \mathrm{Feb}$. 1921. The final part of the letter is devoted to T.'s great admiration and appreciation of Prijatelj's scientific work 
corroborated by his promises to study his books and studies and concludes with T.' sincere apologies for not being able to write to his superior in Slovene.

The other two letters are actually two receipt forms proving that dr. Prijatelj paid his membership for the years 1921 and 1922. Far more interesting are the two enclosures, namely two annual balances for the mentioned years. Evidently the recipient was entitled to these documents either as the faculty dean or as a member of the Executive Board of the French Institute. The figures are particularly interesting because these were the first years of the Institute founded by Tesnière. Let me quote only two items from these balances. The total annual income for the year 1921 amounted to $29.058 \mathrm{FF}$ while $5205 \mathrm{FF}$ was spent on books. The next year's total income was increased by approximately $70 \%$ and reached $46.117 \mathrm{FF}$ while the sum of money spent on books reached $9133 \mathrm{FF}$. which represents more than $100 \%$ increase. In the year 1922 for the first time the expenses for the regional French circles are included, e. $g$. Maribor, Ptuj etc. Therefore even these membership receipts and annual balances offer some valuable information about the vitality and fast progress of the newly established Institute, which within the next decade grew up into an important institution.

\section{Letters to Oton Župančič (1878-1949)}

Only two T.'s letters can be found in the very extensive correspondence of our great poet, playwright and translator. Certainly more than this could be expected because of the long lasting contacts between the two gentlemen. The first one was written in Slovene on 23 Sept. 1923 in Ljubljana. Its first part mentions some bills of exchange Župančič was asked to cosign as the president of the Institute, while the second part refers to the forthcoming concert of French music. The Music department of NUK keeps the original programme of this concert which was organized by Glasbena Matica Slovenije and by the French Institute and was held in the Great Hall of Slovene Philharmony on 8 Oct. 1923 at $8 \mathrm{p}$. m. The performance consisted of the lecture on French history expressed through its songs and music and delivered by prof. Lucien de Flagny while the musical part covered 22 songs all harmonized by prof. Flagny and performed by Mr. William Gwin, tenor of the Paris conservatoire. The concert brochure consists of a very neat blueandblack front page and 9 following pages bringing the texts of the songs in French.

T.'s second letter to Župančič was sent from Strasbourg on 26 Jan. 1928. This is an immediate reaction to Ž.'s invitation to his 50th anniversary celebration. T. sincerely regrets his inability to attend the celebration and expresses his best wishes on behalf of his Institute for the Slave Studies of Strasbourg as well as on his own. T.'s great admiration and respect of Ž.'s poetic genius is expressed in the next passage as well as his deep gratitude and appreciation of the poet's translations of some great French literary authors such as A. France and E. Rostand. The décoration of Chevalier 
del'Ordre National de la Légion d'honneur which was awarded to Ž. on 16 Oct. $1923^{1}$ is also mentioned. After these passages of courtesy T. proceeds with the information about a series of lectures on Slovene literature started only the day before. The first lecture was dedicated to Prešeren, our Petrarca, as he puts it, while he wants to finish the course with a lecture on Ž.'s poetry. He explains to his correspondent that his main purpose is to enable the French public at least to taste some of our great poetry and perhaps to recognize it in its general outline. There is a newspaper clipping containing a review of T.'s final lecture, i. e. the one on $\check{Z}$. added to this letter. There is no signature of the author and not even the date or the title of the newspaper on it. It must have been sent later in another letter to the poet or perhaps it was forwarded to him by someone else.

\section{Letters to dr. Anton Debeljak (1887-1952)}

The two letters T. wrote to his friend dr. Anton Debeljak, prof. of French and a translator from French, were written within a long interval of time. They are both in French. The first one, of 1 August 1923, originates from Ljubljana where the two friends probably frequently met. T. is asking Debeljak about some phonological details about the local speech of Šegova vas, his birthplace. He wants to know whether the adverbs in -uma as spoken there, have a rising (acute accent) or a falling (circumflex) accent. He is also asking him for a list of examples with the marked accents and their quality, i. e. skopuma, strahuma. ${ }^{2}$

His next letter to Debeljak was written 15 years later, 10 June 1938, from Montpellier. This time he is clearing out some vagueness about Dom in svet, one of the two leading Slovene magazines for literature and criticism. Due to the editorial crisis only one double number (1/2) of the magazine was issued in the year 1937 as its 50 th yearbook but next year, 1938, DiS continued with another double number (3/4) as nothing would have happened and numbered it again as the 50th yearbook. T. finds this strange numbering somehow difficult to understand and is asking Debeljak whether there are two magazines with the same name. T. also says in this letter how proud he is because Debeljak has put his name in one of his crossword puzzles which is definitely a new field of Slovene culture he has conquered.

In spite of the very long time interval between the two letters T. doesn't mention any breaks in their correspondence so that one cannot help being sure that there must have been more written contacts between the two friends. Hopefully they will come out sooner or later.

1 This document is kept in the Manuscript collection, NUK Ms $5 / 85,1$.

2 Pleteršnik provides the following varieties (Slovensko-nemški slovar. Drugi del P-Ž. Ljubljana: Knezoškofijstvo, 1895) for Dolenjsko: skôpoma, strahóma. 


\section{Letters to dr. Joža Glonar (1885-1946)}

It has already been stated that this is the most extensive correspondence even though there are only ten letters alltogether, two of them quite brief. J. G. was the chief librarian at the State Library in Ljubljana which functioned as the national and the central university library at the same time. Tesnière was its regular visitor and as such established good contacts with Glonar soon after his arrival in Ljubljana. They also had professional interests in common. As it is well known Glonar was preoccupied both with the Slovene grammar and lexicography: Naš jezik (Our language) 1919, Slovar tujk (Dictionary of foreign words) 1927 and 1934, Poučni slovar 1929-1934, our first encyclopaedic dictionary, Slovensko-nemški slovar (Slovene-German Dictionary) 1934-1935, and his best work Slovar slovenskega jezika (Dictionary of Slovene Language) 1935-1936.

The correspondence with Glonar started in Ljubljana in $1924(?)^{3}$ with a T.'s brief letter of thanks for Glonar's new data on the dual in Slovene.

The first letter from Strasbourg is dated 24 April 1924, immediately after his return to France. This is certainly one of the most illuminating T.'s letters containing several important pieces of information. First of all he states that he has taken over his cathedra for the Slavic languages with pleasure and satisfaction. There he found a well organized seminar founded by prof. Mazon. For the time being he only teaches Russian and old Church Slavic. Further on he is asking Glonar to keep giving him assistance in clearing out some details connected with his work on the dual in Slovene that he himself could not verify while he was still there. Of course he is also expressing his gratitude and sincere thanks for helping him with the library funds as well as for making his research work in Slovenija easier and more successful. Finally he is asking him to write to him in Slovene because he would like to keep in touch with the language and still improve his knowledge if possible.

The third letter, of 19 Oct. 1924, refers to Tenière's great work on the dual in Slovene which, as he puts it, makes progress with a reasonable slowliness. He has already treated a good hundred questionnaires and hopes he would master the total material within a few months. He also complains about some particular printing signs that do not exist in France but would be necessary to print some specialities from Pleteršnik's dictionary.

The other important matter which becomes the main point in their future correspondence is the acquisition of the recent Slovene scientific and literary works in the humanities. The matter was of paramount importance for Tesnière because of his regular Chronicle in the Revue des Etudes Slave (RES). Therefore he is asking Glonar already in this first letter from France to send him the current production regularly. 
There is a complete set of this excellent magazine in our National library still available in the main reading room. It's a great pleasure to look at these volumes documenting T.'s extremely accurately written comments on all relevant books and magazines in humanities from the year 1922 onwards till 1935.

At the end of this letter he also mentions the Slovene colony in Strasbourg mentioning some of its remarkable members, e.g. Benon Gregorič, a former bank director in Ljubljana, Miss Valjavec, specializing in pediatrics, a relative of Matija Valjavec-Kračmanov, prof. Tominšek's daughter etc.

His next letter, the fourth one, of 2 Jan. 1925, is his second longest containing about 1000 words. At this time the problem of getting relevant Slovene books for his Chronicle has reached the boiling point. T. says that the only Slovene publication which has reached him since his departure from Slovenija is the special issue of the magazine Nova Europa, dedicated to Slovenija. It has made him happy but could not relieve his great embarassment due to the complete lack of suitable material to write about in RES. ${ }^{4}$ That's why T. underlines that his Chronicle in RES is seriously endangered and mentions that he has already asked Mr. Martel, his successor in Ljubljana, for help and urges Glonar to see to the matter. He wants him to persuade the publishers to recognize their own interst in sending him their novelties regularly so that Slovene science, culture and literature can be adequately represented in France. First of all he wants everything of some importance having been printed since March 1924, to be sent to him at once.

His fifth letter left France on 18 March 1925. In the introductory part T., as practically in all his letters, asks his collegue to write to him in Slovene because he is afraid of losing the idiomatic charm and the music of the Slovene language. As for his elaborate work Les forms du duel en Slovène he states that it has absorbed him completely as it is approaching its definite version and conclusion. He is complaining about very demanding typographic complications which require 5-6 corrective readings what is a very tiresome and timeconsuming work. The acquisition problem of Slovene books is again the central point dealt with in this letter. He has finally found out that the books sent from Ljubljana some time before remained lying in Paris and did not reach him in time. Therefore he wants Glonar to send him directly to his personal address. This time T. also sets a list of 10 books urgently needed in order to report on them in his Chronicle. Three of them are of particular importance: F. Stele, The Outline of Slovene Art, A. Sič, National Style of a Farmhouse in Gorenjsko Region, and J. Mal, History of Art in Slovenija, Croatia and Serbia. He also mentions that he has finally received Ramovš's Consonantism, one of the crucial works of Slovene philology. As we know T. studied this work very thorougly and wrote a detailed review of it. This is also the work that caused some controversies between Ramovš and Tesnière later.

4 I checked up T.'s section from this period and indeed he could only fill one page, while his normal contribution regularly covered 3-5 printed pages. 
Finally, T. is looking forward to receiving the parcel of the latest Slovene book production which will enable him to convey his project of presenting Slovene literature and science to the French public. It is his firm decision to carry it out as soon as his great work on the dual in Slovene is completed. Perhaps he will even get an opportunity to travel to Slovenija again and shake hands with his numerous friends over there.

His sixth letter, 15 Dec. 1925, introduces a new topic, the history of Slovene language. $T$. was requested to write a study on the historical development of this language but does not have enough sources for it. First of all he needs the text called "Književni dogovor" (Literary Agreement) in its original Serbo-Croat version. His other request is the report of two Slovene linguistic conferences in Vienna 1820 and 1849 where several members of our older and younger generation of Slavic philologists took part, from Kopitar and Metelko to young Levstik.

At the end of this letter $\mathrm{T}$. is expressing Glonar his gratitude for his favourable review of his recently published work Les Formes du duel en Slovène in Slovenec (1925, n. 212).

The next letter follows after six months, 13 April 1926. T. is still working on his article about the history of Slovene language. This time he is asking Glonar for another two documents: The act of the Austrian Ministry of Science from 6 Feb. 1851 dealing with the conclusion of the "Alphabet dispute" as quoted by I. Grafenauer in his Kratka zgodovina slovenskega slovstva (A Short History of Slovene Literature) and the Act of Pokrajinska uprava za Slovenijo (Regional administrative board for Slovenija) about the pronunciation of $-\mathrm{lec},-\mathrm{vec}, \mathrm{i}$. e. bralec, bravec. He also urgently needs two books: Levec: Slovenski pravopis (Slovene Ortography) and Levstik's Slovnica (Grammar). Of course he adds his thanks for all the help he has been offered so far when working on his article and especially for Glonar's extensive and favourable review of his book in Ljubljanski zvon (1926, 313-316).

The last three T.'s letters are unfortunately far less exhaustive and much shorter. The first one, 26 March 1928, is just a brief note in Slovene letting his friend informed about the enclosed reviews of the books Glonar has sent to him. But there is only a small clipping about Glonar's Pocket dictionary of foreign words enclosed.

The next note, again in Slovene, was written almost 2 years later, 30 Jan. 1931. This time he is sending his thanks for Župančič's Epithalamium which reminds him of so pleasing Slovene speech he used to enjoy in Ljubljana.

The last T.'s letter to Glonar is dated 15 Sept. 1934 and consists of only a few sentences. First we learn that he has just finished his Russian grammar and wants Glonar to write a short review of it in order to pave its way to the users. He also hopes that he has alreday received his theoretical article on general syntax. The letter is concluded with his hope to travel to Ljubljana soon and meet him in person.

Tesnière's letters to Glonar cover a decade between 1924-1934 and provide some relevant documentary material of his life and work of this time. They are especially 
important because they prove that Tesnière kept lasting and authentic contacts with Slovene intelectuals and also that he depended exclusively on the original documents, studies and published works at his reasearch work on Slovene language.

His complete correspondence, however fragmentary it may be, offers valuable information about many other relevant matters, for example about the fact that his great work on the dual in Slovene was received relatively superficially at the time of its publishing, then about his great efforts to compose a relevant collection of Slovene scientific and literary books in France, and finally about his extremely successful instrumentality in spreading the knowledge of our culture in France.

There is no need to mention that all his 17 letters referred to in this report are full of genuine admiration and warm personal feelings for Slovenia, its beauty and its people and above all of our language.

Povzetek

TESNIĖRJEVA KORESPONDENCA V ROKOPISNI ZBIRKI NUK

Tesnièrjevo triletno bivanje $v$ Ljubljani, predvsem pa njegovo znanstveno raziskovanje slovenskega jezika in dokaj temeljito poznavanje slovenske literature je bilo nujno povezano tudi $z$ osebnimi stiki s slovenskimi jezikoslovci, besednimi umetniki in kulturnimi delavci. O teh stikih v Rokopisni zbirki NUK hranimo 17 dragocenih Tesnièrjevih pisem Antonu Debeljaku (2, 1923-1938), Joži Glonarju (10, 1924-1934), Ivanu Prijatelju (3, 1921-1923) in Otonu Župančiču $(2,1923-1928)$. To je naša doslej evidentirana Tesnièrjeva korespondenca, zanesljivo pa se bo počasi nabralo še kaj več, saj upravičeno pričakujemo, da si je dopisoval tudi $z$ drugimi sočasnimi vidnimi Slovenci, npr. F. Kidričem, F. Ramovక̌em, R. Kolaričem, J. Šolarjem, morda tudi క̌ z A. Ocvirkom idr.

T-ova korespondenca $v$ NUK je zanimiva tudi vsebinsko. $\mathrm{V}$ tem prispevku podrobneje analiziramo pisma vsakemu naslovniku posebej. Ivanu Prijatelju kot svojemu univerzitetnemu dekanu in članu Francoskega inštituta piše povsem službeno. Z Antonom Debeljakom razpravlja o strokovnih stvareh, npr. o slov, vokalizmu. $O$. Župančiču piše zelo spoštljivo in z občudovanjem njegove poezije ter naznanja svoja predavanja o slov. poeziji. Pomembni pa so tudi podatki o denarnem poslovanju Francoskega inštituta, zlasti tista mesta, ki govorijo o nabavi francoskih knjig za Slovenijo. Najobsežnejša je korespondenca z J. Glonarjem (10 pisem), ki ga naslavlja s prijateljem, sicer pa ga predvsem prosi za temeljne slovenske knjige $s$ področja literarne zgodovine, jezikoslovja in etnologije, o katerih želi poročati v svoji stalni rubriki v Revue des Etudes Slave (RES), ter poroča o francoskih odzivih na slov. literaturo.

Obstoječa korespondenca je kljub razmeroma skromnemu obsegu vreden gradivski prispevek k virom za raziskovanje Tesnièrjevega življenja in dela. 